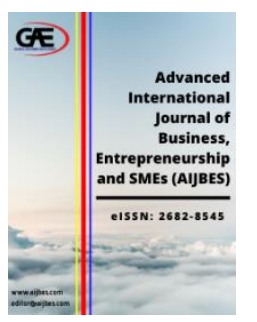

\author{
ADVANCED INTERNATIONAL JOURNAL OF \\ BUSINESS, ENTREPRENEURSHIP AND SMES \\ (AIJBES) \\ WwW.aijbes.com
}

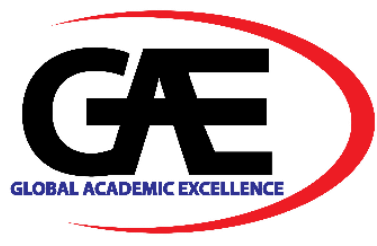

\title{
THE EFFECTIVENESS OF DOVE CAMPAIGN FOR REAL BEAUTY IN AFFECTING CUSTOMERS' PURCHASE DECISION TOWARD DOVE PRODUCTS
}

\author{
Dita Indah Syaharani ${ }^{*}$ \\ 1 School of Business and Management, Institut Teknologi Bandung, Indonesia \\ Email: dita_indah@sbm-itb.ac.id \\ * Corresponding Author
}

\section{Article Info:}

Article history:

Received date: 27.06.2021

Revised date: 21.07 .2021

Accepted date: 26.08.2021

Published date: 09.09.2021

\section{To cite this document:}

Syaharani, D. I. (2021). The Effectiveness Of Dove Campaign For Real Beauty In Affecting Customers' Purchase Decision Toward Dove Products. Advanced International Journal of Business, Entrepreneurship and SMEs, 3 (9), 244-264.

DOI: 10.35631/AIJBES.39017.

This work is licensed under $\underline{\mathrm{CC} B Y} 4.0$

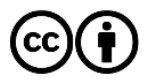

\begin{abstract}
:
The emergence of social marketing campaign strategy has encouraged businesses to adopt it as their marketing strategy. However, although nowadays companies are continuously creating unique social marketing campaigns, many of them end up backfiring. Therefore, companies should create campaigns that are able to draw customers to participate and create purchase decisions. Dove brings a campaign that promotes women's self-esteem through brand building and serves dual goals to make women feel more beautiful and sell more products, called Dove Campaign for Real Beauty. This study aims to analyze how the campaign affects customers' purchase decisions toward the products. From the study, the factors in the campaign that affect customers' purchase decisions toward the products will be identified. Finally, this study aims to develop marketing recommendations for the campaign to affect customers' purchase decisions toward the products. This study uses semi-structured interviews and online survey methods to collect data and uses open coding and PLS-SEM to analyze the relationship between the variables. The results indicate that positive word-of-mouth significantly affects consumer-campaign (CC) identification, perceived cause-related marketing (CRM) motive significantly affects emotional attachment, and affective reaction, brand trust, and brand community significantly affect customers' purchase decision through attitude toward the campaign, attitude toward the brand, and purchase intention. This study is expected to enhance marketer understandings of how the company could improve purchase decisions through social marketing campaign strategy.
\end{abstract}

Keywords:

Attitude Toward the Brand; Attitude Toward the Campaign; Purchase Decision; Purchase Intention; Social Marketing Campaign 
Volume 3 Issue 9 (September 2021) PP. 244-264

DOI 10.35631/AIJBES.39017

Dove is a well-known personal care brand that sells a variety of personal care products such as soaps, body washes, and body lotions manufactured by the Unilever Corporation (Murray, 2013). According to The Brands (2020) ranking, Dove has been listed as one of the top brands in 78 rankings worldwide since 2009. Other than that, based on the brand value ranking on Statista (2020) shown on Figure 1.1, Dove is listed as one of the top brands with the 9th highest brand value among the other personal care brands worldwide in the year of 2020. With these achievements, it becomes reasonable that Dove is considered as one out of all the leading personal care companies in the world (Millard, 2009). As a worldwide company, now Dove products, with developing product lines varying from deodorants, body washes, hair care, lotions, to facial care products, has been sold to 150 countries including Indonesia. In fact, Unilever Indonesia, as the company owning Dove brand, became one of the "50 Asia Top Performing Company" and was awarded as the No. 1 Unilever Company in Asia (Noeryani, 2008).

These successes certainly cannot be separated from the marketing strategies that Unilever has conducted for its individual brands. Dove, besides having the competitive advantages of running its brand under the parent brand of Unilever and high R\&D spends for the product development (Marketing91, 2020), has been known for its remarkable marketing strategies. Other than the advertisements, sales promotion, event, public relations, online and social media marketing of Dove, one of the most popular marketing strategies that Dove has conducted is its social marketing campaigns that bring the issues of women's beauty. On its official website, Dove stated that they hold to the value that beauty is not merely one dimensional nor defined by a woman's shape, age, even size of her body or hair and skin's colour. Rather than that, beauty is how a person feels like they are in their best version. Dove also states that they would like to encourage all women to reach their self potential by having them engaged with the products that offer superior care for the consumers (dove.com). With these values that Dove is trying to promote, Dove becomes one of the companies in the world that actively spreads positivity towards women's beauty through various social marketing campaigns.

On its official website, Dove stated that they hold to the value that beauty is not merely one dimension. Through its company's website, Dove shares all the campaigns they are undergoing. On its website's "Campaigns" sections, there are various names of campaigns with different themes, namely \#BeautyBias which is a film series that aim to dig into how the standards and biases of 2 beauty could affect every aspect of people's life, Dove Self-Esteem Project with the missions to help women in the next generation realize their full potential and to ensure that they are able to grow up with nurturing a positive connection with their appearance, My Beauty My Say which features stories of women who stand up for the beauty that they own, Dove Real Beauty Sketches which aims to help women reconsider their view of their own beauty by involving artists in creating their face sketches, etc (dove.com). These campaigns are mostly presented in the form of YouTube videos or advertisements. ional nor defined by a woman's shape, age, even size of her body or hair and skin's colour. Rather than that, beauty is how a person feels like they are in their best version. Dove also states that they would like to encourage all women to reach their self potential by having them engaged with the products that offer superior care for the consumers (dove.com). With these values that Dove is trying to promote, Dove becomes one of the companies in the world that actively spreads positivity towards women's beauty through various social marketing campaigns.

All these campaigns are held under the main campaign of Dove called Dove Campaign for Real Beauty, which is known as a campaign that promotes women's self-esteem by generating Copyright $\odot$ GLOBAL ACADEMIC EXCELLENCE (M) SDN BHD - All rights reserved 


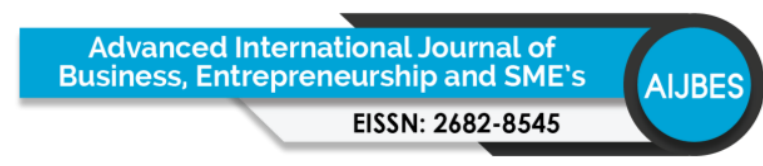

Volume 3 Issue 9 (September 2021) PP. 244-264

DOI 10.35631/AIJBES.39017

awareness through campaigns and brings two main goals, which are to help women feel more beautiful and to sell more products by Dove (Feng et al., 2019). The practice of this campaign fits with the idea of social marketing, which is described as the use of commercial marketing technologies to the process of analysing, planning, executing, and evaluating programs aimed to affect the target audiences' voluntary behaviours, hence improving the society's personal welfare (Andreasen, 2002). Dove Campaign for Real Beauty is constructed from the global Dove's 2003 research regarding "The Real Truth of Beauty" (Murray, 2013) and was initiated in the year of 2004 to challenge the standards of American beauty by presenting ordinary women who are not flawless or skinny and are able to represent a variety of races, sizes, ethnicities, and ages. It turned out that over the decades, Dove has launched a number of new categories within its campaign which also target new audiences, but all bring the same value to be spread, that all women are beautiful (Prior, 2004) which could already be seen in the previous figure. As a result of the campaign, Dove owned the Real Beauty's brand equity, hence without having to mention Dove products, sales could rise (Morel, 2009).

The emergence of social marketing campaign strategy similar to Dove Campaign for Real Beauty discussed above, has encouraged various industries to adopt it as their marketing strategy. However, as a response to the emergence of social marketing campaigns existing these days, Arli \& Dietrich (2017) argued that although more and more businesses were continuing to create various social marketing campaigns that encourage audiences to share the messages carried within the campaigns, many of them still ended up backfiring, such as receiving anger and outrages from the audiences or experiencing backlash, decrease in sales, until product boycotts by the customers. Therefore, as a way to prevent these campaign backfires, companies need to ensure the effectiveness of the social marketing campaigns that are able to draw the customers to participate. This participation can be in the form of likes, comments, and shares for online campaigns, or word-of-mouth spread to the people around them. Il-Hyuna \& Zamrudi (2018) suggested that an overall understanding of the consumers are needed to help the brands make effective and efficient campaigns that can also especially be led toward specific motivation, which is to promote the expected behaviors of contribution, consumption, or creation.

A social marketing campaign consists of stages which start from building awareness and creating interest to get the attention and understanding of the audiences toward the messages, changing attitudes and conditions of the stage to establish audiences' positive intention and attitude toward the messages delivered, and finally, motivating consumers in making purchase decisions. Therefore, it can be concluded that social marketing campaigns aim to transform the intention of the consumers into a real action, which is to make a decision to buy (Purba \& Mawardi, 2017).

Several campaigns are brought under the name of Dove Campaign for Real Beauty which serves as the main campaign conducted by Dove. Each campaign has its own theme, purpose, and program to deliver its purpose and attain its goal. Nowadays, even though Dove is already one of the top brands of personal care brands worldwide (Millard, 2009), the market competition in the beauty and personal care sector in Indonesia also keeps getting tighter (Roesfitawati, 2017). Therefore, besides initially being created to spread the positivity about women's beauty as its purpose, the campaign must be done effectively and efficiently in order for Dove to keep up and compete with other personal care brands. Ideally, the goal of these campaigns should also be for companies to make a purchase decision, as the issues regarding the behavior of purchasers in the market is considered a highly important and crucial Copyright $\odot$ GLOBAL ACADEMIC EXCELLENCE (M) SDN BHD - All rights reserved 
component in the process of creating the modern business marketing strategy (Wiśniewska, 2005). And in order to make the purchase decision, Dove should understand what factors affect customers' purchase decisions towards the products.

During the past decades, there have been a number of social marketing campaigns that eventually failed to affect the purchase decision of customers, which can be caused by the wrong messages brought through the campaigns or because of other factors that eventually led the company to backlash or decreasing financial performances. An example of a failed social marketing campaign is Pepsi's campaign in 2017 which depicted the celebrity and model, Kendall Jenner, participating in a street protest while lending a bottle of Pepsi to the police officer. This campaign resulted in anger and outrages by the viewers due to the insensitivity of how it trivializes the topic of racism and political activism arising those days (EZMarketing, 2019). Another campaign that is very famous for its failure is the New Coke Switch by CocaCola which caused backlash from the customers, decrease in sales, until product boycotts (Jones, et al., 2015). Dove, through its Dove Campaign for Real Beauty, had also experienced a backfire from the body positive packaging in which they produced limited edition packaging in different shapes to represent women's bodies. This campaign instead evoked negative perceptions from the customers that they are forcing women to pick a bottle that only matches their body shapes (Lally, 2020). Nevertheless, in the case of Dove Campaign for Real Beauty, it has been discovered that overall, $76 \%$ of the viewers perceived the women in the ads as beautiful and 68\% described that the ads are able to make them think differently about the brand (Russell, 2009). Therefore, Morel (2009) argued that the campaign turns out to be effective in terms of the society and the brand. Through the campaign, Surdu also argued that Dove has been able to achieve the objective of empowering women to be aware of their beauty instead of targeting an unattainable standard. Dieny (2015) furthermore explained that through the campaign, Dove was able to draw customers' emotions to generate brand equity and positive response toward the company.

However, despite having been conducted for many years and was found to be able to increase the awareness of customers about women's beauty and generate positive responses from customers, Dove Campaign for Real Beauty is still perceived by the audiences to have so much controversy, from being called "hypocritical" until "sneaky". Many critics are thrown to the messages brought by the campaign advertisements, which caused the customers to feel doubtful towards the Dove brand (Celebre \& Denton, 2014). Negative responses have been given to its advertisements, such as the three-second body wash advertisement released on October 2017 which showed black women lifting their shirts to reveal a white women and ended up making Dove denounced for racism (Zed, 2019). With these controversies, it becomes reasonable that Dove experienced a crisis on 2017 (Zed, 2019) and Dove Campaign for Real Beauty advertisements are seen as nothing more than a marketing ploy to make profit for a greedy company that cares more about pushing their products sales (Scott, 2013), hence this problem needs to be solved since consumers might reject the legitimacy and trustworthiness of Dove Campaign for Real Beauty (Celebre \& Denton, 2014) and this may affect to the purchase decision of the customers toward Dove products.

Therefore, this particular study is necessary to understand the perception of customers or audiences regarding Dove Campaign for Real Beauty, specifically the campaign that is in the form of advertisements, and how it finally affects their purchase decision. The advertisements are chosen as the focus of this study since Dove Campaign for Real Beauty is mainly created and brought to customers in the form of videos that are advertised in the media. The Copyright $\odot$ GLOBAL ACADEMIC EXCELLENCE (M) SDN BHD - All rights reserved 
Volume 3 Issue 9 (September 2021) PP. 244-264

DOI 10.35631/AIJBES.39017

advertisements, as previously discussed, have also had some controversies and problems which caused backlash to the company, hence strengthening the reason to focus on these advertisements of Dove Campaign for Real Beauty in this study. This study then discovers the effectiveness of Dove Campaign for Real Beauty in affecting customers' purchase decisions towards Dove products in order to help solve the problem discussed previously by understanding the factors in Dove Campaign for Real Beauty that can positively affect the customers' purchase decision. From the study, the factors that affect customers' purchase decisions are identified and finally, after the first and second steps are examined, the study can provide marketing recommendations to be implemented on Dove Campaign for Real Beauty to positively affect customers' purchase decisions towards Dove products.

\section{Literature Review}

There are fourteen points that will be discussed in literature review, as follows.

\section{Word of Mouth}

Dove Campaign for Real Beauty is recognized as a movement that has inspired and results in resulting in worldwide success through one of the most powerful forms of advertising, which is word of mouth (Harris, 2020). Women began entering blogs willingly and conversing with friends, neighbors, and teachers about the campaign (Morel, 2009). Word-of-mouth is defined as "oral person to person communication between a receiver and a communicator whom the receiver perceives as non-commercial, regarding a brand, a product or a service" (Arndt, 1967). Similarly, Harrison-Walker (2001) then defined WOM as "informal, person-to-person communication between a perceived non-commercial communicator and a receiver regarding a brand, a product, an organization, or a service". Based on previous studies, positive word of mouth significantly influences consumer- campaign identification (Arli and Dietrich, 2017). The study by Chiu and Tseng (2016) supports this statement with the findings that when consumers perceive the presence of a positive word of mouth, they will have a higher level of customer-community identification towards the community. In contrast, it has been found that negative word of mouth from a campaign would negatively influence the consumer-campaign identification, in which the consumers will less likely identify themselves with the company (Arli and Dietrich, 2017).

\section{Consumer-Campaign Identification}

Dove Campaign for Real Beauty delivered advertisements that compelled people to rethink their own perceptions of beauty by strongly connecting them with relatable individuals (Morel, 3009). Previously, study had shown that 76 percent of women wished the media portrayed female beauty as more than just physical attractiveness and 85 percent agreed that every woman has something about her that is beautiful (Mitchell, 2005). With the message brought by Dove Campaign for Real Beauty, Dove is able to make women connected and identify themselves to the discourse of the campaign (Goins, 2016). The concept of consumer-campaign identification came from the concept of consumer- company identification in social identity theory which defines identification as the perception of oneness with or belongingness to a group, involving direct or vicarious experience of its successes and failures (Ashforth and Mael, 1989) and the concept of organizational identification which Dutton, Dukerich, and Harquail (1994) defines as the sense of connection between an individual and an organization. Consumer-company identification itself is described as $\mathrm{s}$ a cognitive state of connection and proximity of consumers to a company (Bhattacharya and Sen, 2003) or a cognitive state related to consumer closeness and connection to a company or brand (Dutton, Dukerich, \& Harquail, 1994). Prior study by Chaudary and Ali (2016) has found that higher customer-company identification leads to better 
attitudes towards an organization or product. In this research, the consumer-company identification is specified as consumer-campaign identification.

\section{Perceived Cause-Related Marketing (CRM) Motive}

Murray (2013) identified the Dove Campaign for Real Beauty as one form of cause-branding effort, by utilizing the concept of "real beauty" in their marketing techniques to engage and increase the customers, while disguising corporate strategy as a selfless cause (Breen, 2014). It is also perceived as a revolutionary cause marketing campaign that encouraged women all around the world to reconsider their perceptions of beauty (Morel, 2009). Cause-related marketing $(\mathrm{CRM})$ is defined as the general alliance between business and non-profit cause that provide resources and funding to address social issues and business marketing objectives (Cui et al., 2003). More specifically, Varadarajan and Menon (1988) described cause-related marketing as "the process of formulating and implementing marketing activities that are characterized by an offer from the firm to contribute a specified amount to a designated cause when customers engage in revenue-providing exchanges that satisfy organizational and individual objectives". The consumers' positive perceptions of motive for CRM campaigns serves as an important antecedent of CRM effectiveness (Pertiwi and Balqiah, 2016).

The previous study by Dunn and Hoegg (2014) found that the perception that the consumer and the brand shared the same or relatable experience will mediate the relationship between fear and emotional brand attachment. Similarly, So, Parsons, and Yap (2013) found that consumers' favorable perceptions towards functional benefits and symbolical benefits which include the brands' values, meanings, and attributes, can result in emotional attachment between the consumers and the brand. The study by Barreda, et al. (2020) supported these findings by suggesting that affective relations that result in consumers' commitment and influence their perceptions should be constantly built to establish emotional connections with the consumers. In this research, the consumers' perception is specified as the perceived causerelated marketing (CRM) motive of consumers towards Dove Campaign for Real Beauty.

\section{Emotional Attachment}

Dove Campaign for Real Beauty employs consumer-appealing tactics such as attaching customers through emotional appeal to empower women to believe in its beauty. This fits the argument that an advertising should not only inform the customers about the product, but it should also attempt to establish an emotional connection with the customer (Morel, 2009). Attachment is an emotion-laden target-specific bond between a person and a specific object (Bowlby, 1979) and is also defined as a disposition to seek proximity and contact with another individual who is the object of attachment (Bowlby, 1988). In the context of a brand, emotional brand attachment is defined as the bond which connects a consumer to a brand characterized by feelings of affection, connection and passion, in which affection represents consumers' feelings of peace, love and friendliness towards a brand, connection describes the feelings of being attached and bonded with a brand, while passion explains the feelings of consumers' delight and captivation with a brand (Thomson et al., 2005).

Prior study by Mogaji and Danbury (2017) found that when a consumer can relate to an advertisement, an emotional connection will be developed, hence affecting the attitude of the consumers in which they want to engage and see what the brand of the advertisement offers. In other words, the study suggested that an emotional attachment can enhance attitudinal loyalty to the brand. The consistent result is also found by Sciulli, Bebko, and Bhagat (2017) 
that there is a positive relationship between the emotion aroused by an advertisement and the attitudes toward the advertisement.

\section{Affective Reaction}

Dove is seen to be able to produce a stimulus in the form of a good campaign design and put it correctly on Dove Campaign for Real Beauty, hence drawing customers' attention and assisting consumers in comprehending the message until it eventually results to the affective responses and attitudes that Dove expects (Hardianto, 2019). According to Solomon et al. (2013), an attitude consists of three components known as the ABC model of attitudes, namely affect (the way a consumer feels about an attitude object), behaviour (the person's intentions to do something with regard to an attitude object), and cognition (the beliefs a consumer has about an attitude object). In the context of advertisements, the attitude toward ads consists of two dimensions, known as the cognitive dimension and emotional or affective reaction (Shimp, 1981). The affective component of attitude is defined as a person's feelings or emotions about the attitude object (Solomon et al., 2013) and affective reaction as the immediate emotional response to the product or service that are usually resulted based on a whim (Lantos, 2011). Wibisono (2017) stated that affective reaction has a positive relationship with the attitude towards Tokopedia storytelling ads on Youtube. These findings are consistent with the study by Machleit and Wilson (1988) that suggested the emotional feelings, which in this research was described as having the same meaning with affective response, affects attitude toward the advertisement.

\section{Cognitive Evaluation}

Morel (2009) argued that advertising now should no longer aim to only sell a product and all ads need to have both a rational and emotional appeal, although one is almost always more pervasive. Dove Campaign for Real Beauty, besides being known as a cause marketing, should also be able to not only rely on emotional appeal, but re-establish itself as a quality brand by delivering product quality messages that are wrapped in rational appeal. Solomon et al. (2013) stated that an attitude consists of three components known as the ABC model of attitudes which consists of affect (the way a consumer feels about an attitude object), behaviour (the person's intentions to do something with regard to an attitude object), and cognition (the beliefs a consumer has about an attitude object). Similarly, Schiffman and Wisenblit (2015) presents a tri-component attitude model which shows that attitude consists of three components, which are cognitive, affective, and conative components. According to Schiffman and Wisenblit (2015), the cognitive component of attitude consists of a person's cognitions which is the knowledge and perceptions of the features of an attitude object that the person acquired from direct experience with the attitude object and information from various sources. The study by Wibisono (2017) whose study shows that cognitive evaluation has a positive relationship with the attitude toward the advertisement of Tokopedia on YouTube.

\section{Brand Image}

Dove Campaign for Real Beauty aims to empower women by promoting the idea of being themselves and create new ways to perceive beauty, body image and self-esteem which fit their brand image of simplicity, purity, and innocence (Zeid, 2010). Brand image is defined by Hofstede et al. (2007) as a set of beliefs held about a specific brand and subjective perceptions of associations. Image is able to create importance and help consumers gather information, distinguish the brand, create reason to purchase, create constructive feelings, and provide basis for brand extension (Aaker, 1991). Therefore, to sustain a brand image is considered as a strategically important and essential part of a company's marketing strategies (Roth, 1995). In 
Volume 3 Issue 9 (September 2021) PP. 244-264

DOI 10.35631/AIJBES.39017

prior study, it has been found that image congruence has a positive and significant relationship with attitude towards advertisement (Paul and Bhakar, 2017). This is consistent with the study by Maulina (2020) which verified that brand image has a positive effect on the attitude of the consumers.

\section{Brand Awareness}

Regarding brand awareness, Dove was reported to be among the top of mind brands in the shower gel, skin and body care segment (Pereira, 2014). According to Keller (1993), the concept of brand awareness refers to a consumer's ability to identify the brand under different conditions and consists of brand recall and brand recognition performance. Macdonald and O'Reilly et al. (2007) stated that brand awareness is critical to achieving broader strategic objectives since consumers may feel better about the brand because of the effect triggered through exposure inside the stadium. A number of previous studies have discussed the relationship between brand awareness and attitude. The study by Biscaia, et al. (2013) found that the awareness of sponsorship significantly influences the attitude toward the sponsorship which will be the strongest predictor of purchase intentions. Jensen and Limbu (2016) supported this finding with similar result that the awareness of social media presence is positively associated with attitudes toward the social media campaign.

\section{Brand Trust}

Vivek, Beatty, and Morgan (2012) suggested that consumer (or potential customer) participation on an online campaign may foster trust because people would believe that the firm cares about them and has their best interests in the heart. In business context, trust can be defined as a consumer's confident beliefs that he or she can rely on the seller to deliver promised services, whereas a relational value can be defined as consumer's perceptions of the benefits enjoyed versus the cost incurred in the maintenance of an ongoing exchange relationship (Agustin and Singh, 2005). Chaudhuri and Holbrook (2001) defined brand trust as the willingness of the average consumer to rely on the ability of the brand to perform its stated function. The previous definitions imply that when consumers trust a brand, they are confident that their desires will be met by the brand, instead of fearing the opposite (Ballester and Aleman, 2005). Therefore, brand trust is considered as an important component in determining an individual's attitude in a business relationship, hence consequently, managers need to recognize it as a key driver in the success of business transactions (Toufaily, Souiden, and Ladhari, 2013). Chaudhuri and Holbrook (2001) stated that brand trust is positively related to attitudinal loyalty and purchase loyalty. The result is consistent with the findings by Hershberger (2017) which stated that there is a moderating effect of trust on attitudes toward the advertisement and the study by Soh, Reid, and King (2009) which shows that consumer trust is significantly and positively correlated with attitude toward advertisement.

\section{Brand Community}

Dove created a connection between women nationally and beyond borders, which was predicted to drive the Dove Campaign for Real Beauty (Friedman, 2015). Casaló, Favián and Guinalíu (2008) defined brand community is a group of people who share the same interest in a particular brand or product. With the rise of mass media, these communities are spread and reproduced very efficiently, which allows community members to possess a well-developed sense of vast unmet fellow community members, to imagine them (Muniz and O'Guinn, 2001). Thus, a brand community can exist everywhere, including virtually (Thompson and Sinha, 2008). The importance of brand communities are found as they represent a form of consumer agency and represent an important information resource for consumers, and communal Copyright $\odot$ GLOBAL ACADEMIC EXCELLENCE (M) SDN BHD - All rights reserved 
Volume 3 Issue 9 (September 2021) PP. 244-264

DOI 10.35631/AIJBES.39017

interaction provides wider social benefits to the members, often affectual, while brand communities likewise provide these (Muniz and O'Guinn, 2001). In a previous study, Chiang, Lo, and Wang (2017) has found that perceived social tie which represent a brand community enhances attitude in the form of sharing, commenting, and creating behaviour related to social media advertising

\section{Attitude Toward the Campaign}

The attitude towards the advertisement is defined as a predisposition to respond in a favourable or unfavourable manner to a particular advertising stimulus during a particular exposure occasion, and the determinants include the viewer's attitude towards the advertiser, evaluations of the ad execution itself, the mood evoked by the ad, and the degree to which the ad affects viewers' arousal levels (Solomon et al., 2013). Therefore, the attitude towards the advertisement should be a useful predictor of consumers' behavior towards a product or service (Oskamp, 1997). In this research, attitude toward the advertisement is defined as the degree of predisposition to which the customers respond either in favourable or unfavourable manner to a campaign advertisement of Dove Campaign for Real Beauty.

There have been a number of studies discussing the relationship between attitude toward the advertisement and attitude toward the brand. The first study was conducted by Shimp (1981), which introduced the concept termed the attitude toward the advertisement approach and showed that the attitude toward the advertisement is transferred to attitude toward the brand. Brown and Stayman (1992) then suggested a significant relationship between ad attitude and a number of important constructs including brand attitude. The study by Goldsmith, Lafferty, and Newell (2000) supported these statements with the finding that attitude toward the ad positively and directly relates to attitude toward the brand. Consistently, the same results that attitude toward the advertisement has a positive relationship and significant effect on attitude toward the brand are generated in the study by Friman (2010) and Sallam, Fahad, and Algammash (2016).

\section{Attitude Toward the Brand}

Phelps and Hoy (1996) defined attitude toward brand as a predisposition to respond in a favorable or unfavorable manner to a particular brand after the advertising stimulus has been shown to the individual. Spears and Singh (2004) later defined attitude toward brand as a relatively enduring, unidimensional summary evaluation of the brand that presumably energizes behavior. Furthermore, brand attitude was conceived as unidimensional and treated as a summary evaluation to distinguish it from the evaluation which is implicit in beliefs, feelings, behaviors, and other components and expressions of attitudes. These definitions support the argument that as the consumer is exposed to an advertisement, its influence can be observed through consumer's reactions such as his/her persuasion speech about the brand on other people and his/her own behavior towards it (Wahid and Ahmed, 2011) and that there is a strong positive relationship between attitude towards the advertisement and attitude towards the brand which implies that a consumer who enjoyed or did not enjoy a particular advertisement is likely to hold a favourable or unfavourable attitude towards the brand advertised (Sicilia, Ruiz, and Reynolds, 2006).

Goldsmith, Lafferty, and Newell (2000) has found that attitude toward the brand positively and directly relates to purchase intention, which is supported in the study by $\mathrm{Wu}$ and Lo (2009) that found a significant and positive effect of core-brand attitude on consumers' purchase intention. Furthermore, other studies by Sallam, Fahad, and Algammash (2016), Lee, Lee, and Yang 
(2017), and Maknunah and Rachmat (2020) show consistent results that attitude toward the brand has significant and positive effect on purchase intention.

\section{Purchase Intention}

Shah et al. (2012) defined purchase intention as a kind of decision-making that studies the reason to buy a particular brand by consumer. Purchase intention is an element of a consumer's cognitive behaviour revealing the way an individual intends to purchase a specific brand ( $\mathrm{Su}$ and Huang, 2010), which consists of some processes starting from identifying problems, searching for information, assessing alternatives, making the purchase, to post-purchase behavior (Farr \& Hollis, 1997). Purchase intention usually is related to the behavior, perceptions and attitudes of consumers (Mirabi, 2015) and is considered an effective tool to predict the buying process of consumers (Ghosh, 1990). Thus, purchase intention has been regarded as one of the most significant sections in the business field (Xiao, Yang, and Iqbal, 2018). Prior study by Kim, Ferrin, and Rao (2008) found that a consumers' intention to purchase positively affects the purchase decision, which is supported in the study by Ariff (2014) that discovered how purchase behavior is significantly affected by the purchase intention of the products. Z., Suharyono, and Kumadji (2016) on the study about electronic word of mouth, showed consistent result that purchase intention has a significant influence toward purchasing decision, followed with the study by Rachbini (2018) and Harum, Kusumawati, and Mawardi (2021) that also found positive impact and significant influence of purchase intention on purchase decision of consumers.

\section{Purchase Decision}

Purchase decision is a consumer behaviour to make choices from two or more brand alternatives through the decision process to reach a choice for the most preferred brand (Karimi, Papamichail, and Holland, 2015). Kotler and Armstrong (2014) defined purchase decision as a buyer's decision-making stage in which an individual decides to actually buy the product being considered. Furthermore, it is explained that a purchase decision is the decision regarding a brand to be purchased. Liang and Lai (2002) adopted the EKB model which divides consumer decision processes into five stages, consisting of problem recognition, search for information, evaluation of alternatives, choice, and outcome evaluation. And the sixth stage becomes the transaction that occurs after the consumer has chosen the product. Similarly, Kotler et al. (2005) divided the purchase decision process into five stages, which are need recognition, information search, evaluation of alternatives, purchase decision, and post purchase behavior.

\section{Conceptual Framework}

The proposed conceptual framework is utilized and evaluated in a future study based on this research. The conceptual model is checked using mixed method, qualitative methods using semi-structured interview and quantitative methods by distributing questionnaires and analyzed with statistical tests. After evaluating the previous study, this study generates 15 latent variables and 52 indicators with the following conceptual framwork as follows. 


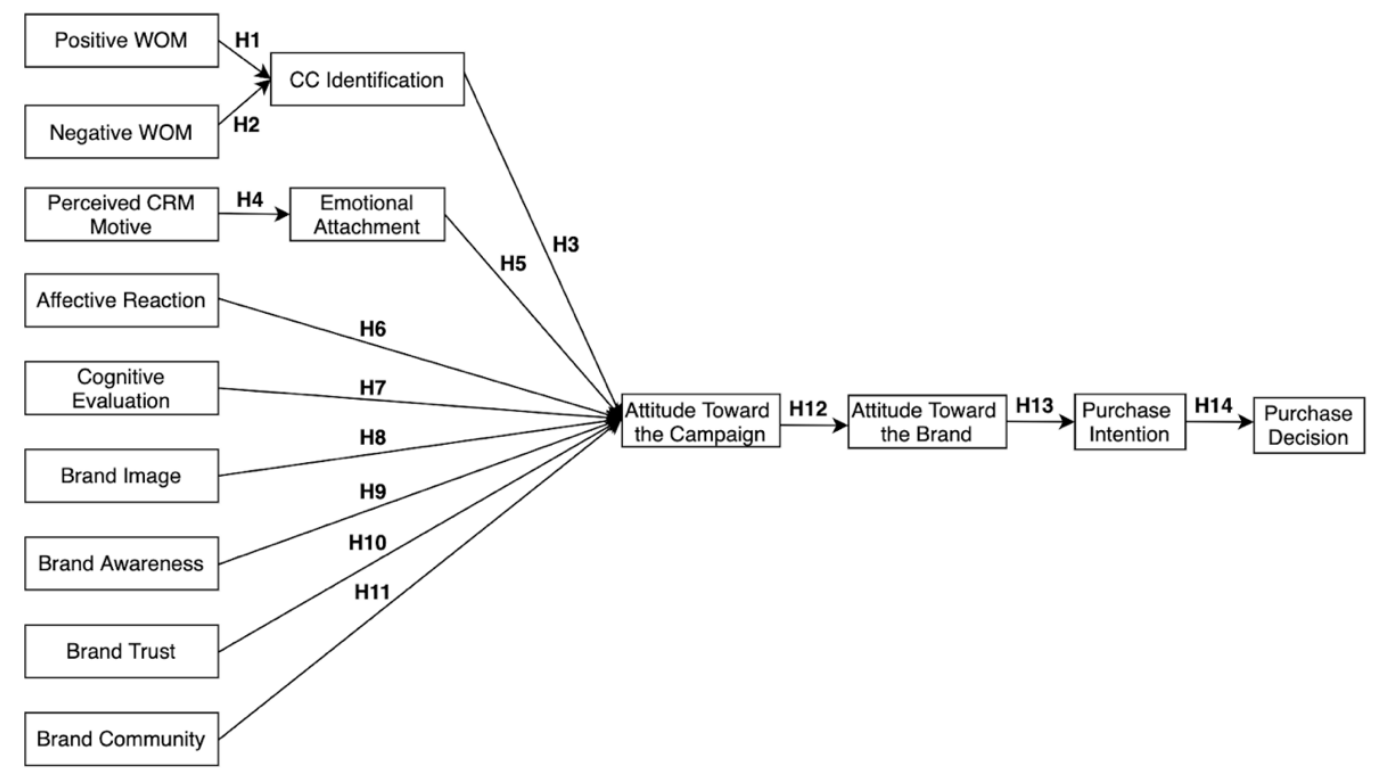

Figure 1: Conceptual Framework

H1: Positive word of mouth positively affects consumer-campaign identification.

$\mathrm{H} 2$ : Negative word of mouth negatively affects consumer-campaign identification.

H3: Consumer-campaign identification significantly affects attitude toward the campaign.

H4: Perceived cause-related marketing motive significantly affects emotional attachment.

H5: Emotional attachment significantly affects attitude toward the campaign.

H6: Affective reaction significantly affects attitude toward the campaign.

H7: Cognitive evaluation significantly affects attitude toward the campaign.

H8: Brand image significantly affects attitude toward the campaign.

H9: Brand awareness significantly affects attitude toward the campaign.

H10: Brand trust significantly affects attitude toward the campaign.

H11: Brand community significantly affects attitude toward the campaign.

H12: Attitude toward the campaign significantly affects attitude toward the brand.

H13: Attitude toward the brand significantly affects purchase intention.

H14: Purchase intention significantly affects purchase decision.

\section{Methodology}

\section{Qualitative Approach}

Qualitative approach is used in this research to have initial information and deep insights towards the issues being researched, which is used to generate the variables indicators that are going to be measured and validated in the quantitative approach through survey. The qualitative approach used in this research is a semi-structured interview which involves a series of openended questions based on the topic areas the researcher wants to cover. For this research, the respondents are women in Indonesia from any age who have watched the campaign video of Dove Campaign for Real Beauty and have purchased Dove products and the interviewees are asked about their perceptions and opinions about Dove Campaign for Real Beauty, the factors influencing their perceptions and opinions toward the campaign, and how the campaign affect their purchase decision towards Dove products. In the qualitative approach, this study uses non-probability sampling, specifically purposive sampling and open coding is used in analyzing the qualitative data of this research. 


\section{Quantitative Approach}

In this research, the quantitative approach is used to generate objective measurement and the numerical data collected through the survey method, hence transformed to statistical data and used to break down the problem. Survey method is the method used in this research and will be done through questionnaire that contains a set of questions to record respondents' answers (Sekaran \& Bougie, 2003). The population of this research consists of women in Indonesia from any age who have watched the campaign video of Dove Campaign for Real Beauty and have purchased Dove products. This study collects a total of 250 survey responses as the data to be analyzed. In this research, purposive sampling technique will be used for the survey. Descriptive statistics is used to analyze quantitative data in this research to provide a summary of the samples and measures done on a study (Sharma, Sohil). The researcher uses Partial Least Square (PLS) to process the data in this study. The PLS-SEM includes assessments of reliability test, validity test, collinearity test, structural path significance in bootstrapping, coefficient of determination $\left(\mathrm{R}^{2}\right)$ and stone-geisser test $\left(\mathrm{Q}^{2}\right)$, f square effect size, total indirect and total effect, and mediating result.

\section{Results}

This research shows the respondent's response to some factors from Dove Campaign for Real Beauty relating to customers' decision in purchasing Dove products.

Table 1: Hypothesis Testing Result

\begin{tabular}{|c|c|c|c|c|c|}
\hline Hypothesis & Structural Path & $\begin{array}{c}\text { Original Sample } \\
(\mathbf{O})\end{array}$ & T-Values & P Value & Result \\
\hline H1 & $\begin{array}{c}\text { Positive Word-of- } \\
\text { Mouth -> Consumer- } \\
\text { Campaign (CC) } \\
\text { Identification }\end{array}$ & 0,530 & 8,435 & 0,000 & Accepted \\
\hline H2 & $\begin{array}{c}\text { Negative Word-of- } \\
\text { Mouth -> Consumer- } \\
\text { Campaign (CC) } \\
\text { Identification }\end{array}$ & 0,121 & 2,573 & 0,010 & Rejected \\
\hline H3 & $\begin{array}{c}\text { Consumer-Campaign } \\
\text { (CC) Identification -> } \\
\text { Attitude Toward the } \\
\text { Campaign }\end{array}$ & $-0,145$ & 1,638 & 0,102 & Rejected \\
\hline H4 & $\begin{array}{c}\text { Perceived Cause- } \\
\text { Related Marketing } \\
\text { (CRM) -> Emotional } \\
\text { Attachment }\end{array}$ & 0,495 & 7,970 & 0,000 & Accepted \\
\hline H5 & $\begin{array}{c}\text { Emotional Attachment } \\
\text {-> Attitude Toward the } \\
\text { Campaign }\end{array}$ & 0,016 & 0,237 & 0,813 & Rejected \\
\hline H6 & $\begin{array}{c}\text { Affective Reaction -> } \\
\text { Attitude Toward the } \\
\text { Campaign }\end{array}$ & 0,431 & 6,194 & 0,000 & Accepted \\
\hline Cognitive Evaluation - & 0,093 & 1,288 & 0,198 & Rejected \\
\hline
\end{tabular}


Volume 3 Issue 9 (September 2021) PP. 244-264

DOI 10.35631/AIJBES.39017

\begin{tabular}{|c|c|c|c|c|c|}
\hline & $\begin{array}{c}>\text { Attitude Toward the } \\
\text { Campaign }\end{array}$ & & & & \\
\hline $\mathrm{H} 8$ & $\begin{array}{c}\text { Brand Image -> } \\
\text { Attitude Toward the } \\
\text { Campaign }\end{array}$ & 0,031 & 0,431 & 0,667 & Rejected \\
\hline $\mathrm{H} 9$ & $\begin{array}{c}\text { Brand Awareness -> } \\
\text { Attitude Toward the } \\
\text { Campaign }\end{array}$ & 0,135 & 1,646 & 0,100 & Rejected \\
\hline H10 & $\begin{array}{c}\text { Brand Trust -> } \\
\text { Attitude Toward the } \\
\text { Campaign }\end{array}$ & 0,254 & 3,295 & 0,001 & Accepted \\
\hline H11 & $\begin{array}{c}\text { Brand Community -> } \\
\text { Attitude Toward the } \\
\text { Campaign }\end{array}$ & 0,140 & 2,576 & 0,010 & Accepted \\
\hline H12 & $\begin{array}{c}\text { Attitude Toward the } \\
\text { Campaign }->\text { Attitude } \\
\text { Toward the Brand }\end{array}$ & 0,690 & 13,876 & 0,000 & Accepted \\
\hline H13 & $\begin{array}{c}\text { Attitude Toward the } \\
\text { Brand -> Purchase } \\
\text { Intention }\end{array}$ & 0,594 & 9,574 & 0,000 & Accepted \\
\hline H14 & $\begin{array}{l}\text { Purchase Intention -> } \\
\text { Purchase Decision }\end{array}$ & 0,583 & 13,272 & 0,000 & Accepted \\
\hline
\end{tabular}

\section{Discussion}

There are two informants for the interviews, which are two consumers of Dove products who have watched the video of Dove Campaign for Real Beauty. Based on the interview results, people's opinion about the message shared on Dove Campaign for Real Beauty video varied and showed positive responses. It is concluded that people like the message of Dove Campaign for Real Beauty video. While for the dislikes about Dove Campaign for Real Beauty video, it turns out that one of the dislikes is the absence of men in the campaign video. Based on the interview result, it shows that people's perception about Dove after watching Dove Campaign for Real Beauty video is that Dove is an inclusive brand. It is found that watching Dove Campaign for Real Beauty video influences them to purchase Dove products or to consider purchasing Dove products. However, it is also found that besides the influence of the campaign video, they also purchase Dove products because of the good quality.

For the questionnaire result, based on the hypothesis testing, there are eight hypothesis being accepted and six hypothesis being rejected. It is found that positive word-of-mouth positively affects consumer-campaign identification, negative word-of-mouth does not negatively affect consumer-campaign identification, consumer-campaign identification does not significantly affect attitude toward the campaign, perceived cause-related marketing (CRM) motive significantly affects emotional attachment, emotional attachment does not significantly affect attitude toward the campaign, affective reaction significantly affects attitude toward the campaign, cognitive evaluation does not significantly affect attitude toward the campaign, brand image does not significantly affect attitude toward the campaign, brand awareness does not significantly affect attitude toward the campaign, brand trust significantly affects attitude toward the campaign, brand community significantly affects attitude toward the campaign, 
attitude toward the campaign significantly affects attitude toward the brand, attitude toward the brand significantly affects purchase intention, and purchase intention significantly affects purchase decision.

After evaluating the questionnaire and interview result, it is found that Dove Campaign for Real Beauty affect customers' purchase decisions toward Dove products through a number of variables. According to the result of PLS analysis, customers' purchase decision toward Dove products are affected by affective reaction, brand trust, and brand community through attitude toward the campaign, attitude toward the brand, and purchase intention. These findings are also consistent with the results obtained through interviews. It is proved that the affective reaction and brand trust could significantly affect the customers' attitude toward the campaign positively, meaning that the better or higher the affective reaction and brand trust, the better the attitude toward the campaign become. Similarly, an understanding and motivation to participate in the brand community could significantly affect the customers' attitude toward the campaign. Attitude toward the campaign then can significantly affect the attitude toward the brand, which can significantly affect purchase intention and consequently, the purchase intention can significantly affect the purchase decisions toward Dove products. Those were how Dove Campaign for Real Beauty affect customers' purchase decisions toward Dove products.

\section{Conclusion}

There are a number of factors in Dove Campaign for Real Beauty that affect customers' purchase decisions toward Dove products, which are affective reaction, brand trust, and brand community through attitude toward the campaign, attitude toward the brand, and purchase intention. Therefore, there are some marketing recommendations to be implemented on Dove Campaign for Real Beauty to affect customers' purchase decisions toward Dove products, which are to maintain spreading the message and awareness for the cause brought in Dove Campaign for Real Beauty, to increase brand trust by delivering true, reliable, and honest messages on the campaign, and to create a formal community of women who are willing to support and spread the message of the campaign while creating a call-to-action message on the campaign video that encourages the existing community to directly participate in the campaign.

However, this research is limited to women in Indonesia from all ages who have watched campaign videos of Dove Campaign for Real Beauty and have purchased Dove products. And the videos of Dove Campaign for Real Beauty studied in this research are limited to the "Dove \#RealBeauty Is Universal | Celebrate all types of beauty" and the "Dove Real Beauty Sketches" campaign videos. The research is conducted for the period of time from April 2021 until July 2021. In reality, the viewers of Dove Campaign for Real Beauty are not only women, and the users of Dove products also include men, specifically for the men's products since Dove is also selling personal care products for men. Therefore, it is possible that the video of Dove Campaign for Real Beauty is watched by men and consequently affect their purchase decision toward Dove products. Therefore, for future research, it is suggested to include not only women, but also men respondents. Furthermore, this research tried to find significant factors in Dove Campaign for Real Beauty that can positively affect customers' purchase decision toward Dove products and had evaluated a number of variables, namely positive and negative word-of-mouth, consumer-campaign identification, perceived CRM motive, emotional attachment, affective reaction, cognitive evaluation, brand image, brand awareness, brand trust, and brand community. However, not all of these variables evaluated become the factors that positively affect customers' purchase decision toward Dove products. Therefore, in future Copyright (C) GLOBAL ACADEMIC EXCELLENCE (M) SDN BHD - All rights reserved 
Volume 3 Issue 9 (September 2021) PP. 244-264

DOI 10.35631/AIJBES.39017

research, it is suggested to find other factors in Dove Campaign for Real Beauty that could positively affect customers' purchase decision toward Dove products.

\section{References}

Aaker, D. A. (1991). Managing brand equity: Capitalising On The Value Of A Brand Name. Free Press.

Aaker, D. A. (2002) Building Strong Brands. Free Press.

Agustin, Clara \& Singh, Jagdip. (2005). Curvilinear Effects of Consumer Loyalty Determinants in Relational Exchanges. Journal of Marketing Research - J MARKET RES-CHICAGO. 42. 96-108. 10.1509/jmkr.42.1.96.56961.

Ajzen, I. (1991). The theory of planned behavior. Organizational Behavior and Human Decision Processes, 50, 179-211. doi:10.1016/0749-5978(91)90020-T

Andreasen, A. R. (2002). Marketing social marketing in the social change marketplace. Journal of Public Policy and Marketing, 21(1), 3-13. https://doi.org/10.1509/jppm.21.1.3.17602

Ariff, M. (2014). Consumers perception, purchase intention and actual purchase behavior of organic food products.

Arli, D., \& Dietrich, T. (2017). Can Social Media Campaigns Backfire? Exploring Consumers' Attitudes and Word-of-Mouth Toward Four Social Media Campaigns and Its Implications on Consumer-Campaign Identification. Journal of Promotion Management, 23(6), 834-850. https://doi.org/10.1080/10496491.2017.1323259

Arndt, J. (1967). Word of mouth advertising: A review of the literature. New York, NY: Advertising Research Foundation.

Ashforth, B. E., \& Mael, F. (1989). Social identity theory and the organization. Academy of Management Review, 14(1), 20-39.

Baek, W.; Byon, K.K.; Choi, Y.; Park, C. Millennial Consumers' Perception of Sportwear Brand Globalness Impacts Purchase Intention in Cause-Related Product Marketing. Soc. Behav. Personal. 2017, 45, 1319-1336.

Ballester, E. Delgado and Aleman, F. Munuere (2005). Does brand trust matter to brand equity. Journal of Product and Brand Management, 14 (3), 187-196.

Barreda, Albert \& Nusair, Khaldoon \& Wang, Youcheng \& Okumus, Fevzi \& Bilgihan, Anil. (2020). The impact of social media activities on brand image and emotional attachment: A case in the travel context. Journal of Hospitality and Tourism Technology. ahead-ofprint. 10.1108/JHTT-02-2018-0016.

Bhattacharya, C. B., \& Sen, S. (2003). Consumer-Company Identification: A Framework for Understanding Consumers' Relationships with Companies. Journal of Marketing, 67(2), 76-88. doi:10.1509/jmkg.67.2.76.18609

Biscaia, Rui \& Correia, Abel \& Ross, Stephen \& Rosado, António \& Maroco, João. (2013). Sport Sponsorship: The Relationship Between Team Loyalty, Sponsorship Awareness, Attitude Toward the Sponsor, and Purchase Intentions. Journal of Sport Management. 27. 288-302. 10.1123/jsm.27.4.288.

Bowlby, J. (1979). Loss: Sadness and depression. New York, NY: Basic Books

Bowlby, J. (1988), A Secure Base: Parent-Child Attachment and Healthy Human Development, Basic Books Inc., Publishers, New York, NY.

Breen, Claire. (2014). "Real Beauty" Campaigns in the Media: Dove Campaign for Real Beauty Brown, Steven \& Stayman, Douglas. (1992). Antecedents and Consequences of Attitude Toward the Ad: A Meta-Analysis. Journal of Consumer Research. 19. 34-51. $10.1086 / 209284$. 
Volume 3 Issue 9 (September 2021) PP. 244-264 DOI 10.35631/AIJBES.39017

Casaló, Luis V., Flavián Carlos, and Miguel Guinalíu. 2008. "Promoting Consumer's Participation in Virtual Brand Communities: A New Paradigm in Branding Strategy." Journal of Marketing Communications 14: 19-36.

Celebre, Angela \& Denton, Ashley W. (2013). The good, the bad, and the ugly of the Dove Campaign for Real Beauty. Retrieved August 4th, 2021, from https://www.inmind.org/article/the-good-the-bad-and-the-ugly-of-the-dove-campaign-for-real-beauty

Chaudary, Samra \& Ali, Muhammad. (2016). The spillover effect of CSR initiatives on consumer attitude and purchase intent: The role of customer-company identification with the moderating effect of awareness.

Chaudhuri, A., \& Holbrook, M. B. (2001). The Chain of Effects from Brand Trust and Brand Affect to Brand Performance: The Role of Brand Loyalty. Journal of Marketing, 65(2), 81-93. doi:10.1509/jmkg.65.2.81.18255

Chaurasiya, Rachana. (2015). Product Name Dove Soap. Retrieved August 4th, 2021, from http://docshare01.docshare.tips/files/24260/242602131.pdf

Chiang, I., Lo, S., \& Wang, L.-H. (2018). Customer Engagement Behaviour in Social Media Advertising: Antecedents and Consequences. Contemporary Management Research, 13(3). https://doi.org/10.7903/cmr.17673

Cone, C.L.; Feldman, M.A.; DaSilva, A.T. Causes and Effects. Harv. Bus. Rev. 2003, 81, 95101.

Cui, Y., Trent, E. S., Sullivan, P. M., \& Matiru, G. N. (2003). Cause-related marketing: how generation Y responds cause-related marketing: how generation Y responds. Journal of Retail and Distribution Management, 31(6), 310-320. http://doi.org/10.1108/09590550310476042

Dita. (2016). PENGARUH BRAND EXTENSION TERHADAP LOYALITAS PELANGGAN PRODUK DOVE PADA PT. UNILEVER INDONESIA PADA TAHUN 2016

Dobni, Dawn and Zinkhan, George M. (1990) ,"In Search of Brand Image: a Foundation Analysis", in NA - Advances in Consumer Research Volume 17, eds. Marvin E. Goldberg, Gerald Gorn, and Richard W. Pollay, Provo, UT : Association for Consumer Research, Pages: 110-119.

Dove. Dove Self-Esteem Project. Retrieved February 1, 2021, from https://www.dove.com/us/en/stories/about-dove/dove-self-esteem-project.html

Dove. My Beauty My Say. Retrieved February 1, 2021, from https://www.dove.com/us/en/stories/campaigns/my-beauty-my-say.html

Dove. Real Beauty Sketches. Retrieved February 1, 2021, from https://www.dove.com/us/en/stories/campaigns/real-beauty-sketches.html

Dove. \#BeautyBias. Retrieved February 1, 2021, from https://www.dove.com/us/en/stories/campaigns/-beautybias.html

Dunn, Lea \& Hoegg, JoAndrea. (2014). The Impact of Fear on Emotional Brand Attachment. Journal of Consumer Research. 41. 152-168. 10.1086/675377.

Dutton, J. E., Dukerich, J. M., \& Harquail, C. V. (1994). Organizational images and member identification. Administrative Science Quarterly, 39, 239 -263.

Einwiller, S. A. (2006). Enough Is Enough! When Identification No Longer Prevents Negative Corporate Associations. Journal of the Academy of Marketing Science, 34(2), 185-194. doi:10.1177/0092070305284983

Elshof, Paul. (2005). Unilever Company Profile. Retrieved August 4th, 2021, from https://www.somo.nl/wp-content/uploads/2005/07/Company-Profile-Unilever.pdf 
Volume 3 Issue 9 (September 2021) PP. 244-264 DOI 10.35631/AIJBES.39017

Farr, A., \& Hollis, N. (1997). What do you want your brand to be when it grows up: Big and strong? Journal of Advertising Research, 37(6), 23-36. Retrieved from https://www.warc.com/fulltext/jar/9078.htm

Feng, Y., Chen, H., \& He, L. (2019). Consumer Responses to Femvertising: A Data-Mining Case of Dove's "Campaign for Real Beauty" on YouTube. Journal of Advertising, 48(3), 292-301. https://doi.org/10.1080/00913367.2019.1602858

Fishbein, M. \& Ajzen, Icek. (1975). Belief, attitude, intention and behaviour: An introduction to theory and research.

Fournier, Susan. (1998). Consumers and Their Brands: Developing Relationship Theory in Consumer Research. Journal of Consumer Research. 24. 343-73. 10.1086/209515.

Friedman, Peter. (2015). Dove Campaign for Real Beauty: 3 Social Media Lessons from Advertising Age's Best Campaign of the 21st Century. Retrieved August 4th, 2021, from

https://info.liveworld.com/hubfs/eBooks/3_Social_Media_Lessons_from_Advertising _Ages_Best_Campaign_of_the_21st_Century_-_Dove_CFRB.pdf

Friman, J. (2010). Consumer attitudes toward mobile advertising.

Ghosh, A. 1990. Retail management. Chicago: Drydden press.

Goins, K. E. (2016). Dove Campaign for Real Beauty. Retrieved August 3rd, 20201, from https://ir.ua.edu/bitstream/handle/123456789/2647/file_1.pdf?sequence=1\&isAllowed $=\mathrm{y}$

Goldsmith, Ronald \& Lafferty, Barbara \& Newell, Stephen. (2000). The Impact of Corporate Credibility and Celebrity on Consumer Reaction to Advertisements and Brands. Journal of Advertising. 29. 43-54. 10.1080/00913367.2000.10673616.

Hardianto, Antonius Widi. (2019). ANALISIS STIMULUS-ORGANISM-RESPONSE MODEL PADA "DOVE CAMPAIGN FOR REAL BEAUTY" 2004-2017

Harris, Izzy Liyana. (2020). Dove Empowered Women and Found Success in 80+ Countries. Retrieved August 4th, 2021, from https://www.referralcandy.com/blog/dovemarketing-strategy/

Harum, J., Kusumawati, A., \& Kholid Mawardi, M. (2021), The Effect of Email Marketing Permission on Purchase Intention and Its Impact on Purchase Decision (Survey on Lazada Indonesia's Customers)

Hershberger, E.K. (2017). The moderating role of trust in the Internet on online ad and brand attitude formations.

Hofstede, A., Hoof, J. Van, Walenberg, N., \& Jong, M. De. (2007). Projective techniques for brand image research: Two personification-based methods explored. Qualitative Market Research: An International Journal, 10(3), 300- 309. http://doi.org/10.1108/13522750710754326

Hou, J., Du, L., \& Li, J. (2008). Cause's attributes influencing consumer's purchasing intention: empirical evidence from China. Asia Pacific Journal of Marketing and Logistics, 20(4), 363-380. http://doi.org/10.1108/13555850810909704

Il-Hyuna, B., \& Zamrudi, M. F. Y. (2018). CHALLENGE OF SOCIAL MEDIA MARKETING \&amp; EFFECTIVE STRATEGIES TO ENGAGE MORE C...: Deakin University Library Search. International Journal of Business and Society, 19(3), 851869. http://eds.a.ebscohost.com/eds/pdfviewer/pdfviewer?vid=4\&sid=7b8425804bbe-4287-a3b8-5d849d96e281\%40sessionmgr4008

Jensen, Ricard \& Limbu, Yam. (2016). Spectators' Awareness, Attitudes and Behaviors towards a Stadium's Social Media Campaign. International Journal of Marketing Studies. 8. 44-51. 10.5539/ijms.v8n4p44. 
Volume 3 Issue 9 (September 2021) PP. 244-264 DOI 10.35631/AIJBES.39017

Karimi, S., Papamichail, K. N., \& Holland, C. P. (2015). The effect of prior knowledge and decision-making style on the online purchase decision-making process: A typology of consumer shopping behaviour. Elsevier, 137-147.

Keller, K.L. (1993). Conceptualizing, measuring, and managing customer-based brand equity. JMR, Journal of Marketing Research, 57, 1-22

Keller, K. L. (2003). Strategic brand management: building, measuring, and managing brand equity. Upper Saddle River, Prentice Hall

Kim, Dan \& Ferrin, Donald \& Rao, Raghav. (2008). A Trust-Based Consumer DecisionMaking Model in Electronic Commerce: The Role of Trust, Perceived Risk, and Their Antecedents. Decision Support Systems. 44. 544-564. 10.1016/j.dss.2007.07.001.

Kotler, P. and Armstrong, G. (2014). Principles of Marketing. 15th ed. New Jersey: Pearson Prentice Hall

Kotler, P., Wong, V., Saunders, J., \& Armstrong, G. (2005). Principles of Marketing. Harlow: Pearson Education.

Lantos, G. (2011). Consumer behavior in action: Real-life applications for marketing managers. Armonk, N.Y: M.E. Sharpe.

Lee, Eui-Bang \& Lee, Sang Gun \& Yang, Chang-Gyu. (2017). The influences of advertisement attitude and brand attitude on purchase intention of smartphone advertising. Industrial Management \& Data Systems. 117. 10.1108/IMDS-06-2016-0229.

Levy, S. J. (1959). Symbols for Sale. Harvard Business Review, 117-124.

Liang, T.-P., \& Lai, H.-J. (2002). Effect of store design on consumer purchases: an empirical study of on-line bookstores. Information \& Management, 39(6), 431-444. doi:10.1016/s0378-7206(01)00129-x

Macdonald, E., and Sharp, B. 1996. Management Perceptions of the Importance of Brand Awareness as an Indication of Advertising Effectiveness. Marketing Research On-Line 1 (1996): $1 \pm 15$.

Maknunah, L., \& Rachmat, B. (2020). The Effect of Brand Image, Brand Trust, Economic Benefits, and Brand Attitude Toward Purchase Intention on Iphone in East Java. International Journal of Multicultural and Multireligious Understanding, 7, 308-320.

Marketing91. (2018). Marketing Strategy of Dove - Marketing91. Retrieved October 12, 2020, from https://www.marketing91.com/marketing-strategy-of-dove/

Maulina, Lia. (2020). The Influence of Celebrity Endorser, Fashion Brand Image, and Attitude on Repurchase Intention Trend of Muslim Clothing in Muslim Millenial Generation

Millard, J. (2009). Performing Beauty: Dove's "Real Beauty" Campaign. Symbolic Interaction, 32(2), 146-168. https://doi.org/10.1525/si.2009.32.2.146

Mirabi, D. (2015). A Study of Factors Affecting on Customers Purchase Intention Case Study: the Agencies of Bono Brand Tile in Tehran.

Mitchell, A. A., \& Olson, J. C. (1981). Are Product Attribute Beliefs the Only Mediator of Advertising Effects on Brand Attitude? Journal of Marketing Research, 18(3), 318. doi: $10.2307 / 3150973$

Mogaji, E., \& Danbury, A. (2017). Making the brand appealing: advertising strategies and consumers' attitude towards UK retail bank brands. Journal of Product \& Brand Management, 26(6), 531-544. doi:10.1108/jpbm-07-2016-1285

Molitor, D. (2008, May 1). In Dove We Trust. Hub Magazine.

Morel, L. (2009). The Effectiveness of the Dove Campaign for Real Beauty in Terms of Society and the Brand The Effectiveness of the Dove Campaign for Real Beauty in Terms of Society and the Brand. Syracuse University Honors Program Capstone Projects.

Muniz, A. M., \& O'Guinn, T. C. (2001). Brand Community. Journal of Consumer Research, 27(4), 412-432. doi:10.1086/319618

Copyright $\odot$ GLOBAL ACADEMIC EXCELLENCE (M) SDN BHD - All rights reserved 
Volume 3 Issue 9 (September 2021) PP. 244-264 DOI 10.35631/AIJBES.39017

Murray, D. P. (2013). Branding "Real " Social Change in Dove' s Campaign for Real Beauty BRANDING “ REAL" SOCIAL CHANGE IN DOVE' S CAMPAIGN FOR REAL BEAUTY. December 2014, 37-41. https://doi.org/10.1080/14680777.2011.647963

Noeryani, F. A. (2008). The Representation of Beauty in Indonesia vs. USA Dove Shamphoo Advertisements; $\quad$ A $\quad$ Semiotic Study. Jl, 503-5676. http://gmarcom.wordpress.com/2008/02/p

Oskamp, S., (1997), “Attitudes and Opinions”, Englewood Cliffs, NJ: Prentice Hall

O’Reilly, N., Nadeau, J., Séguin, B., \& Harrison, M. (2007). In-stadium sponsorship evaluation of a mega-sponsee: The 2004 Grey Cup. International Journal of Sports Marketing \& Sponsorship, 8, 179-198.

Paul, J., \& Bhakar, S. (2017). Does Celebrity Image Congruence Influences Brand Attitude and Purchase Intention? Journal of Promotion Management, 24(2), 153-177. doi:10.1080/10496491.2017.1360826

Pechtl, Hans \& Heidarian, Elham, 2016. "Can a cause-related brand be perceived different from other brands?," Wirtschaftswissenschaftliche Diskussionspapiere 02/2016, University of Greifswald, Faculty of Law and Economics.

Pertiwi, A.L.; Balqiah, E.T. How Consumers Respond to Corporate Social Responsibility Initiative: Cause-Related Marketing vs. Philanthropy. Asean Mark. J. 2016, 8, 136146.

Phelps, Joseph \& Hoy, Mariea. (1996). The Aad-Ab-PI relationship in children: The impact of brand familiarity and measurement timing. Psychology \& Marketing - PSYCHOL MARKET. 13. 77-105. 10.1002/(SICI)1520-6793(199601)13:13.0.CO;2-M.

Prior, M. (2004). Dove's Campaign for Real Beauty. Teachable Moments, 1. http://www.media-

awareness.ca/english/resources/educational/teachable_moments/campaignrealbeauty.c fm

Purba, R. M., \& Mawardi, M. K. (2017). The Influence Of Social Marketing Campaign On Buying (Survey on Students of Brawijaya University' s Perspective about $100 \%$ Cinta Indonesia Campaign). Jurnal Administrasi Bisnis, 50(4), 131-138.

Rachbini, Widarto. (2018). THE IMPACT OF CONSUMER TRUST, PERCEIVED RISK, PERCEIVED BENEFIT ON PURCHASE INTENTION AND PURCHASE DECISION.. International Journal of Advanced Research. 6. 1036-1044. 10.21474/IJAR01/6317.

Ranking The Brands. (2020). Dove Brand Ranking: All brand Rankings where Dove is listed! Retrieved October 12, 2020, from https://www.rankingthebrands.com/Branddetail.aspx ?brandID $=1015$

Roesfitawati. (2017). Health \& Beauty Industry in Indonesia. November, 1-12.

Roth, M. S. (1995). Effects of Global Market Conditions on Brand Image Customization and Brand Performance. Journal of Advertising, 24(4), 55-75. doi:10.1080/00913367.1995.10673489

Rotter, J. B. 1967. A New Scale for The Measurement of Interpersonal Trust. Journal of Personality, 35(4), 651-65.

Sallam, M. A. \& Algammash, F. A. (2016). The Effect of Attitude Toward Advertisement on Attitude Toward Brand and Purchase Intention. International Journal of Economics, Commerce and Management, 4(2), pp. 509-520

Sciulli, L. M., Bebko, C. P., \& Bhagat, P. (2017). How emotional arousal and attitudes influence ad response: Using eye tracking to gauge nonprofit print advertisement effectiveness. Journal of Marketing Management, 5(1), 1-11. doi:10.15640/jmm.v5n1a1 
Volume 3 Issue 9 (September 2021) PP. 244-264 DOI 10.35631/AIJBES.39017

Shah, H., Aziz, A., Jaffari, A. R., Waris, S., Ejaz, W., Fatima, M. and Sherazi., K.(2012), The Impact of Brands on Consumer Purchase Intentions, Asian Journal of Business Management 4(2): 105-110

Shimp, T. A. (1981). Attitude toward the AD as a Mediator of Consumer Brand Choice. Journal of Advertising, 10(2), 9-48. doi:10.1080/00913367.1981.10672756

Sicilia, M., Ruiz, S., \& Reynolds, N. (2006). Attitude Formation Onlin - how the Consumer's need for Cognition Affects the Relationship between Attitude towards the Website and Attitude towards the Brand. International Journal of Market Research, 48(2), 139-154. doi:10.1177/147078530604800204

Solomon, M., Bamossy, G., Askegaard, S. \& Hogg, M. (2013). Consumer Behaviour: A European Perspective. 5th edition. New York: Pearson Education

Soh, H., Reid, L., \& King, K. (2009). Measuring Trust in Advertising: Development and Validation of the ADTRUST Scale. Journal of Advertising, 38(2), 83-103. Retrieved April 16, 2021, from http://www.jstor.org/stable/27749637

So, Jing Theng \& Parsons, Andrew \& Yap, Crystal. (2013). Corporate branding, emotional attachment and brand loyalty: The case of luxury fashion branding. Journal of Fashion Marketing and Management. 17. 10.1108/JFMM-03-2013-0032.

Spears, N. \& Singh, S. (2004). Measuring Attitude Toward the Brand and Purchase Intentions. Journal of Current Issues and Research in Advertising 26(2):53-66

Statista. (2020). Brand value of the leading personal care brands worldwide in 2020. Retrieved October 12, 2020, from https://www.statista.com/statistics/273236/brand-value-of-theleading-personal- care-brands-worldwide/

Sukpanich, Nichaya \& Chen, Lei-Da. (1999). Measuring Consumers' Attitudes to Web Advertising, Electronic Markets, 9:1-2, 20-24, DOI: 10.1080/101967899359193

$\mathrm{Su}$, D., \& Huang, X. (2010). Research on Online Shopping Intention of Undergraduate Consumer in China--Based on the Theory of Planned Behavior. International Business Research, 4(1). doi:10.5539/ibr.v4n1p86

Swartz, T. A. (1983). Brand Symbols and Message Differentiation. Advertising Research, 23(5), 59-64.

Thompson, Scott A., \& Sinha, Rajiv K. (2008). Brand communities and new product adoption: The influence and limits of oppositional loyalty. Journal of Marketing, 72(6), 65-80.

Thomson, M., MacInnis, D.J. and Park, C.W. (2005), "The ties that bind: measuring the strength of consumers' emotional attachments to brands", Journal of Consumer Psychology, Vol. 15 No. 1, pp. 77-91.

Toufaily, E., Souiden, N., \& Ladhari, R. (2013). Consumer trust toward retail websites: Comparison between pure click and click-and-brick retailers. Journal of Retailing and Consumer Services, 20 (6), 538-548. doi:10.1016/j.jretconser.2013.05.001

Varadarajan, P. R., \& Menon, A. (1988). Cause-Related Marketing: A Coalignment of Marketing Strategy and Corporate Philanthropy. Journal of Marketing, 52(3), 58. doi:10.2307/1251450

Wahid, N.A., \& Ahmed, M. (2011). The Effect of Attitude toward Advertisement on Yemeni Female Consumers' Attitude toward Brand and Purchase Intention. Global Business and Management Research: An International Journal, 3, 21.

Wibisono, Ignatius Agung. (2017). The Effect of Tokopedia Storytelling Advertisement on Youtube to Customers' Attitudes Toward Brand.

Wiśniewska, A. (2005), Czynniki decydujące o wrażliwości konsumentów na markę, in: Instrumenty kształtowania wizerunku marki, A. Grzegorczyk (ed.), Warszawa: Wyższa Szkoła Promocji. 
Volume 3 Issue 9 (September 2021) PP. 244-264 DOI 10.35631/AIJBES.39017

Wu, Shwu-Ing \& Lo, Chen-Lien. (2009). The influence of core-brand attitude and consumer perception on purchase intention towards extended product. Asia Pacific Journal of Marketing and Logistics. 21. 174-194. 10.1108/13555850910926317.

Xiao, A., Yang, S., \& Iqbal, Q. (2018). Factors Affecting Purchase Intentions in Generation Y: An Empirical Evidence from Fast Food Industry in Malaysia. Administrative Sciences, $9,4$.

Z., Syafaruddin, Suharyono, \& Kumadji, Srikandi (2016), The Effect of Electronic Word of Mouth Communication on Trust and Purchase Intention and Its Impact on Purchasing Decisions

Zed, Olivia. (2019). How Dove's Real Beauty campaign won, and nearly lost, its audience. Retrieved August 4th, 2021, from https://www.prweek.com/article/1582147/dovesreal-beauty-campaign-won-nearly-lost-its-audience

Zeid, Grace Abou. (2010). FUNCTIONAL ANALYSIS of DOVE CAMPAIGN FOR REAL BEAUTY. Retreived August 4th, 2021, from http://www.aou.edu.lb/onlineservices/preface/proj87_fulltext.pdf 